\title{
Kadar Heat Shock Protein 70 pada Persalinan Prematur
}

\author{
Heat Shock Protein 70 Level in Preterm Birth \\ Soetrisno Kasan W, Supriyadi Hari R, Antonius Budi GB \\ Laboratorium Obstetri dan Ginekologi Fakultas Kedokteran Universitas Sebelas Maret Surakarta
}

\begin{abstract}
ABSTRAK
Persalinan preterm merupakan masalah kesehatan bagi negara maju maupun berkembang, berperan besar peningkatan morbiditas dan mortalitas neonatus, serta sering berdampak kesehatan jangka panjang seperti celebral palsy, kebutaan, dan perkembangan psikomotorik. Menganalisis apakah terdapat perbedaan serta hubungan antara kadar HSP70 persalinan preterm dibandingkan kehamilan normal. Observasional analitik dengan rancangan potong lintang. Jumlah subyek penelitian 60 ibu hamil dibagi dua kelompok, persalinan preterm 30 ibu hamil dan kelompok kehamilan normal 30 ibu hamil. Pemeriksaan HSP70 dilakukan di laboratorium klinik Prodia. Analisa statistik dengan uji Chi-kuadrat. Berdasarkan karakteristik ibu pada kedua kelompok penelitian, pendidikan dan LILA (Lingkar Lengan Atas) berpengaruh terhadap kejadian persalinan preterm (Probability $(p)=0,008$ dan $p=0,002)$. Ibu berpendidikan SD mengalami persalinan preterm sebanyak 6,6 kali lebih besar (Prevalence Ratio $(P R)=6,682$ dan $p=0,029$ ), sedangkan berpendidikan SMP berisiko mengalami persalinan preterm sebanyak 3 kali lebih besar ( $P R=3,27$ dan $p=0,054)$ dibanding SMA. Ibu berLILA kurang memiliki risiko persalinan preterm sebanyak 5,5 kali lebih besar dibanding ibu berLILA normal $(P R=5,5)$. Ibu berkadar HSP70 yang tinggi berisiko mengalami persalinan preterm sebanyak 5,2 kali lebih besar dibanding kehamilan normal $(P R=5,26$ dan $p=0,122)$. Ada perbedaan dan hubungan antara kadar Heat Shock Protein 70 persalinan preterm dibandingkan kehamilan normal, namun didapatkan kesimpulan statistik yang tidak bermakna. LILA dan pendidikan berpengaruh bermakna terhadap kejadian persalinan preterm.
\end{abstract}

Kata Kunci: Distres maternal, heat shock protein 70, persalinan preterm, lingkar lengan atas, pendidikan

\begin{abstract}
Preterm birth is a problem for both developed and developing countries, plays a significant increase in neonatal morbidity and mortality, and often gives long-term health impacts such as cerebral palsy, blindness, and psychomotor development. This study analyzes the difference and the relationship between HSP70 level of preterm birth and normal pregnancy. An observational analytic cross sectional design was used. Subjects were 60 pregnant women divided into two groups, i.e. 30 pregnant women with preterm birth and 30 normal pregnancy women. HSP70 examinations were performed at Prodia Laboratory and statistical analysis used Chi square test. Based on the characteristics of the women in both groups, education and MUAC (Mid-Upper Arm Circumference) affect the incidence of preterm birth (Probability $(p)=0,008$ and $p=0,002)$. Mothers graduated from elementary school experienced preterm birth as much as 6.6 times higher (Prevalence Ratio $(P R)=6,682$ and $p=0,029)$, while mothers graduated from junior high school have 3 times higher risk of preterm birth $(P R=3,27$ and $p=0,054)$ compared to mothers graduated from senior high school. Subjects having smaller MUAC have risk of preterm birth 5,5 times more likely than mothers of normal MUAC (PR=5,5). High levels of HSP70 mothers have the risk of preterm birth as much as 5,2 times greater than normal pregnancy $(P R=5,26$ and $p=0,122)$. There is a difference and relationship between Heat Shock Protein 70 level preterm birth compared to normal pregnancy, but no meaningful statistic conclusion is acquired. MUAC and education significantly affect the incidence of preterm birth.
\end{abstract}

Keywords: Education, heat shock protein 70, maternal distress, mid-upper arm circumference, preterm birth

Jurnal Kedokteran Brawijaya, Vol. 28, No. 4, Agustus 2015; Korespondensi: Elok Zubaidah Laboratorium Obstetri dan Ginekologi Fakultas Kedokteran Universitas Sebelas Maret Surakarta, JI. Ir. Sutami No. 36 A Kentingan -Jebres - Surakarta 57126 Tel. (0271) 664178 Email:pogi_surakarta@yahoo.co.id 


\section{PENDAHULUAN}

Persalinan preterm merupakan masalah kesehatan baik di negara maju maupun berkembang. Kejadian persalinan preterm berbeda di setiap negara. Di negara maju, angka persalinan preterm berkisar antara $5-11 \%$, sedangkan di negara berkembang angka kejadian persalinan preterm jauh lebih tinggi. Data angka kejadian persalinan preterm di Indonesia belum ada, namun angka kejadian bayi dengan berat badan lahir rendah (BBLR) dapat mencerminkan angka kejadian persalinan preterm secara kasar. Angka kejadian BBLR nasional rumah sakit adalah $27,9 \%$ (1). Berdasarkan data UNICEF, angka BBLR di negara berkembang yaitu $16 \%$, di mana lebih dari 10 juta BBLR dilahirkan di negara Asia Selatan (2).

Persalinan preterm berperan besar dalam peningkatan morbiditas dan mortalitas neonatus, serta seringkali memberikan dampak kesehatan jangka panjang, seperti cerebral palsy, kebutaan dan gangguan perkembangan psikomotorik $(3,4)$. Persalinan preterm sering berhubungan dengan ketuban pecah dini, inkompetensi serviks, polihidramnion, kelainan janin dan uterus, infeksi, faktor sosial, stres, merokok, kerja berat dan faktor-faktor risiko lainnya (5).

Status sosial ekonomi merupakan suatu konstruksi yang kompleks secara umum digunakan untuk mendefinisikan keberagaman sosial dan biasanya diukur dengan pencapaian pendapatan dan/atau pendidikan. Pendidikan adalah salah satu dimensi status sosial ekonomi yang paling kuat dan konsisten dapat memprediksi luaran kesehatan. Pendidikan ibu merupakan prediktor yang paling kuat terhadap luaran reproduksi pada penelitianpenelitian di Amerika Serikat. Pendidikan yang rendah akan membatasi ibu untuk mendapatkan akses pekerjaan dan kegiatan sosial lain sehingga membatasi ibu terhadap interaksi sosial dan berisiko terhadap kemiskinan. Status sosial ekonomi merupakan salah satu stresor psikososial pada ibu yang akan mempengaruhi luaran kehamilan (6).

Stresor psikososial yang dipicu karena faktor sosial, ekonomi dan pendidikan yang rendah akan menimbulkan persepsi stres. Persepsi stres merupakan tahap awal dalam mengartikan sumber stress yang diterima organ sensoris untuk menentukan ketepatan respon stres. Ibu yang menerima stresor psikososial akan mempersepsikan dan meresponnya sehingga mencapai keseimbangan baru (eustress) atau menyebabkan gangguan keseimbangan (distress) (7). Mekanisme distress karena faktor sosial, ekonomi dan pendidikan yang rendah pada ibu hamil yang menyebabkan terjadinya persalinan preterm belum bisa dijelaskan secara detil, khususnya secara biomolekuler. Penelitian ini bertujuan menjelaskan secara molekuler terjadinya persalinan preterm karena distress yang dipicu faktor sosial, ekonomi dan pendidikan yang rendah.

Keadaan stres maternal akan berpengaruh pada neuroendokrin. Neuroendokrin merupakan proses yang paling penting dalam kaitan antara stres ibu hamil dan kejadian persalinan preterm. Proses neuroendokrin berakibat aktivasi aksis HPA (Hipotalamus-PituitariAdrenal) yang dimediasi oleh $\mathrm{CRH}$ (Corticotropin Releasing Hormone) plasenta. Aktivasi aksis HPA mengakibatkan peningkatan kadar efektor biologis stres, seperti kortisol dan epinefrin, sehingga dapat mengaktivasi ekspresi gen CRH plasenta. CRH plasenta dapat menstimulasi sekresi kortisol, DHEA-S (dehidroepiandrostenedion sulfat) janin, estrogen dan prostaglandin plasenta (8).

Peningkatan kadar kortisol akan mengurangi efek supresi protein miosit sehingga produksi HSP70 meningkat. HSP70 berpengaruh pada peningkatan jumlah kalsium di dalam miosit peningkatan CAMP sitoplasma dan pengaktifan CAMP dependent protein kinase. Selanjutnya terjadi fosforilasi dan inaktivasi myosin rantai kinase sehingga menyebabkan kontraksi otot uterus (7).

Ikatan endogen HSP70 menyebabkan respon inflamasi yang ditandai peningkatan kadar sitokin proinflamasi di dalam cairan amnion dan infiltrasi neutrofil dan makrofag ke dalam miometrium, serviks dan selaput amnion $(9,10)$. Di samping itu CRH menyebabkan aktifasi makrofag yang mensekresi sitokin proinflamasi. Ikatan endogen HSP70 maupun sitokin proinflamasi berakibat aktivasi NF-B dan faktor-faktor transkripsi proinflamasi lainnya di dalam miometrium, epitel serviks dan sel-sel amnion. NF-B yang teraktivasi akan meningkatkan ekspresi gen yang mempromosikan kontraktilitas miometrium, antara lain reseptor $\mathrm{F} 2 \alpha$, protein gap junction-connexin 43 , reseptor oksitosin dan cyclooxygenase-2 (COX-2) (4).

Sitokin proinflamasi dan kontraksi uterus secara sinergis memicu sintesis prostaglandin dan matriks metalloproteinase. Prostaglandin menyebabkan remodeling serviks, sedangkan matriks metalloproteinase menyebabkan robekan selaput ketuban, sehingga berlanjut pada proses persalinan preterm (10). Dalam penelitian ini dilakukan pemeriksaan kadar HSP70 serum ibu hamil yang mengalami persalinan preterm dan kehamilan normal di RSUD Dr. Moewardi, Surakarta, Jawa Tengah. Untuk mengetahui apakah terdapat perbedaan kadar HSP70 pada persalinan preterm dibandingkan kehamilan normal.

\section{METODE}

Penelitian ini merupakan penelitian observasional analitik dengan rancangan penelitian potong lintang. Tempat penelitian di Kamar Bersalin Pelayanan Obstetri Neonatal Emergensi Komprehensif (PONEK), Poliklinik Obstetri RSUD Dr. Moewardi, Surakarta dan Laboratorium Prodia Surakarta dan Jakarta. Waktu penelitian pada tanggal 1 September-14 Desember 2013.

Sampel penelitian terbagi menjadi dua kelompok, yaitu kelompok persalinan preterm dan kelompok kehamilan normal. Sampel penelitian untuk kelompok persalinan preterm (usia kehamilan 28-<37 minggu) adalah ibu yang mengalami persalinan preterm kala I fase aktif (pembukaan serviks $\geq 4 \mathrm{~cm}$ sampai dengan kala II awal). Sampel penelitian untuk kelompok kontrol adalah ibu primigravida kehamilan normal (usia kehamilan $>37-<42$ minggu).

Semua sampel memenuhi kriteria inklusi dan eksklusi. Kriteria inklusi adalah primigravida usia kehamilan 28-<37 minggu, tidak ketuban pecah dini, usia ibu antara 20-35 tahun, status menikah, berpendidikan SD-SMA, kehamilan normal, persalinan aterm dan peserta JAMPERSAL (Jaminan Persalinan). Kriteria eksklusi adalah status tidak dalam ikatan pernikahan atau terancam perceraian, kehamilan yang tidak diinginkan, hipertensi dalam kehamilan, klinis dan laboratories terdiagnosa infeksi genitalia serta diabetes mellitus. 
Penelitian ini telah memenuhi kelaikan etik (ethical clearance) oleh panitia kelaikan etik RSUD Dr. Moewardi Surakarta. Jumlah sampel penelitian dihitung dengan rumus Murti dengan tingkat kemaknaan 0,05, mean difference 29,2 dihitung menggunakan piranti lunak OpenEpi ${ }^{\circledR}$ dan didapatkan jumlah sampel yang dibutuhkan sebanyak 15 dimasing-masing kelompok, sehingga total sampel adalah 30 . Pada penelitian ini dipakai total sampel 60 ibu hamil yang telah memenuhi kriteria inklusi dan eksklusi. Subjek penelitian 2 kelompok, yaitu masing-masing 30 sampel untuk kelompok persalinan preterm dan kehamilan normal.

Pada kedua kelompok penelitian dilakukan pengambilan darah, dicatat data fisik pasien berupa tinggi badan, berat badan, indeks massa tubuh, lingkar lengan kiri atas, tekanan darah sistolik dan diastolik. Darah diambil dari vena cubiti sebanyak $10 \mathrm{cc}$, dibagi dua masing-masing $5 \mathrm{cc}$ untuk pemeriksaan HSP70 dan darah lengkap (gula darah sewaktu, SGOT, SGPT, ureum, kreatinin, kadar hemoglobin, angka leukosit dan protein total). Pemeriksaan darah lengkap langsung dilakukan di Laboratorium Prodia Surakarta. Darah vena cubiti sebanyak $5 c c$ untuk pemeriksaan Hsp-70, segera ditampung di dalam tabung plain yang telah didinginkan pada suhu $2-8^{\circ} \mathrm{C}$. Darah dimasukkan ke dalam tabung dengan cara dialirkan pada dinding tabung untuk mencegah lisisnya sel-sel darah. Setelah darah dimasukkan ke dalam tabung dingin, maka darah dibolakbalik hingga homogen. Label tabung ditulis nomer, nama, usia, tanggal lahir, jenis kelamin dan alamat pasien, tanggal dan jam pengambilan darah.

Tabung yang telah berisi darah dimasukkan ke dalam suhu ruangan $2-8^{\circ} \mathrm{C}$ (sampel tidak boleh kontak dengan icepack) untuk segera disentrifuge pada kecepatan 3000 rotasi per menit selama 15 menit. Serum darah yang didapat segera dipisahkan ke dalam dua sampel cup masing-masing sebanyak $0,3 \mathrm{cc}$ dan diberikan identitas, nama, tanggal dan jenis pemeriksaan, untuk pemeriksaan HSP70 dan sampel cadangan. Dua sampel cup serum untuk pemeriksaan kadar Hsp-70 tersebut dikirim ke Laboratorium Prodia Jakarta dalam suhu $-70^{\circ} \mathrm{C}$ oleh Laboratorium Prodia Surakarta. Satu sampel cup serum langsung diperiksa kadar Hsp-70, satu sampel cup serum yang lain disimpan pada suhu $-20^{\circ} \mathrm{C}$ sebagai sampel cadangan.

Hasil pemeriksaan data kedua kelompok sampel dilakukan uji statistik Chi Kuadrat dengan program SPSS versi 17.0 dan OpenEpi versi 2.0. Tingkat kepercayaan 95\% (Confidence Interval) dan kesimpulan statistik dianggap bermakna jika nilai $\mathrm{p}<0,05$ (11).

\section{HASIL}

Pada Tabel 1 menunjukkan bahwa variabel umur, indeks massa tubuh, kadar hemoglobin, angka leukosit, kadar gula darah sewaktu, SGOT, SGPT, kadar ureum, kadar kreatinin, kadar total protein, tekanan darah sistolik dan diastolik dalam keadaan homogen $(p>0,05)$. Untuk variabel pendidikan dan lingkar lengan kiri atas dalam keadaan tidak homogen yang ditunjukkan dengan nilai $p$ variabel pendidikan $0,008(p<0,05)$ dan variabel lingkar lengan atas kiri $0,002(p<0,05)$ sehingga secara statistik bermakna. Hal ini menunjukkan variabel pendidikan dan LILA mempunyai pengaruh terhadap terjadinya persalinan preterm.
Tabel 1. Karakteristik data ibu pada kedua kelompok penelitian

\begin{tabular}{|c|c|c|c|c|c|}
\hline \multirow[t]{2}{*}{ Karakteristik } & $\begin{array}{c}\text { Persalinan } \\
\text { Preterm }\end{array}$ & $\begin{array}{c}\text { Kehamilan } \\
\text { Normal }\end{array}$ & \multirow[t]{2}{*}{ Rerata } & \multirow[t]{2}{*}{ Median } & \multirow[t]{2}{*}{ p } \\
\hline & N (\%) & N (\%) & & & \\
\hline Umur Ibu & & & 25,48 & 27,5 & 0,323 \\
\hline 20-24 tahun & $13(43,33)$ & $18(60)$ & & & \\
\hline 25-29 tahun & $8(26,67)$ & $4(13,33)$ & & & \\
\hline 30-35 tahun & $9(30)$ & $8(26,67)$ & & & \\
\hline Pendidikan: & & & & & 0,008 \\
\hline SD & $7(23,33)$ & $2(6,7)$ & & & \\
\hline SMP & $12(40)$ & $7(23,33)$ & & & \\
\hline SMA & $11(36,67)$ & $21(70)$ & & & \\
\hline Kelompok IMT: & & & 23,85 & 24,865 & 0,12 \\
\hline$<18,5 \mathrm{~kg} / \mathrm{m} 2$ & $1(3,33)$ & $2(6,67)$ & & & \\
\hline $18,5-25 \mathrm{~kg} / \mathrm{m} 2$ & $23(76,67)$ & $13(43,33)$ & & & \\
\hline$>25 \mathrm{~kg} / \mathrm{m} 2$ & $6(20)$ & $15(50)$ & & & \\
\hline LILA: & & & 24,05 & 24,5 & 0,002 \\
\hline$<23,5 \mathrm{~cm}$ & $22(73,33)$ & $10(33,33)$ & & & \\
\hline$\geq 23,5 \mathrm{~cm}$ & $8(26,67)$ & $20(66,67)$ & & & \\
\hline Hemoglobin & $30(50)$ & $30(50)$ & 10,80 & 12,1 & 0,906 \\
\hline Angka Lekosit & $30(50)$ & $30(50)$ & 7.826 & 7.100 & 0,283 \\
\hline GDS & $30(50)$ & $30(50)$ & 93,72 & 100,5 & 0,188 \\
\hline SGOT & $30(50)$ & $30(50)$ & 19,75 & 23,5 & 0,145 \\
\hline SGPT & $30(50)$ & $30(50)$ & 17,53 & 18,5 & 0,058 \\
\hline Ureum & $30(50)$ & $30(50)$ & 15,93 & 22 & 0,872 \\
\hline Kreatinin & $30(50)$ & $30(50)$ & 0,6 & 0,65 & 0,883 \\
\hline Total Protein & $30(50)$ & $30(50)$ & 6,84 & 6,7 & 0,288 \\
\hline Sistolik & $30(50)$ & $30(50)$ & 113,42 & 115 & 0,154 \\
\hline Diastolik & $30(50)$ & $30(50)$ & 72,92 & 70 & 0,392 \\
\hline
\end{tabular}

Pada Tabel 2 menunjukkan bahwa ibu berpendidikan SD memiliki risiko untuk mengalami persalinan preterm sebanyak 6,6 kali lebih besar dibandingkan ibu berpendidikan SMA (PR=6,682), $p=0,029(p<0,05)$.

Tabel 2. Hasil uji Chi Kuadrat tentang perbedaan persentase kejadian persalinan preterm antara ibu berpendidikan SD dan SMA

\begin{tabular}{lccccc}
\hline & $\begin{array}{c}\text { Persalinan } \\
\text { Preterm }\end{array}$ & $\begin{array}{c}\text { Kehamilan } \\
\text { Normal }\end{array}$ & Total & $\begin{array}{c}\text { Prevalence } \\
\text { Ratio }\end{array}$ & P \\
\hline SD & 7 & 2 & 9 & 6,682 & 0,029* \\
SMA & 11 & 21 & 33 & & \\
Total & 18 & 23 & 42 & & \\
\hline
\end{tabular}

Pada Tabel 3 menunjukan bahwa ibu berpendidikan SMP memiliki risiko untuk mengalami persalinan preterm sebanyak 3,2 kali lebih besar dibandingkan ibu berpendidikan SMA $(P R=3,27), p=0,054(p>0,05)$.

Tabel 3. Hasil uji Chi Kuadrat tentang perbedaan persentase kejadian persalinan preterm antara ibu berpendidikan SMP dan SMA

\begin{tabular}{lccccc}
\hline & $\begin{array}{c}\text { Persalinan } \\
\text { Preterm }\end{array}$ & $\begin{array}{c}\text { Kehamilan } \\
\text { Normal }\end{array}$ & Total & $\begin{array}{c}\text { Prevalence } \\
\text { Ratio }\end{array}$ & P \\
\hline SMP & 12 & 7 & 19 & 3,27 & 0,054 \\
SMA & 11 & 21 & 11 & & \\
Total & 23 & 28 & 30 & & \\
\hline
\end{tabular}


Pada Tabel 4 menunjukkan bahwa ibu dengan LILA kurang memiliki risiko untuk mengalami persalinan preterm sebanyak 5,5 kali lebih besar dibandingkan ibu berstatus gizi baik ( $P R=5,5 ; p=0,002)$.

Tabel 4. Hasil Uji Chi Kuadrat tentang perbedaan persentase persalinan pretermantara LILA kurang dan LILA normal

\begin{tabular}{lccccc}
\hline & $\begin{array}{c}\text { Persalinan } \\
\text { Preterm }\end{array}$ & $\begin{array}{c}\text { Kehamilan } \\
\text { Normal }\end{array}$ & Total & $\begin{array}{c}\text { Prevalence } \\
\text { Ratio }\end{array}$ & P \\
\hline LILA kurang & 22 & 10 & 32 & 5,5 & $0,002^{*}$ \\
LILA normal & 8 & 20 & 28 & & \\
Total & 30 & 30 & 60 & & \\
\hline
\end{tabular}

Pada Tabel 5 menunjukkan bahwa terdapat perbedaan persentase kejadian persalinan preterm antara kadar HSP70 tidak normal dan normal. Ibu mempunyai kadar HSP70 tidak normal berisiko untuk mengalami persalinan preterm sebanyak 5,2 kali lebih besar dibandingkan yang kadar HSP70 normal $(P R=5,27)$, meskipun perbedaan tersebut secara statistik tidak bermakna $(p=0,122)$.

Tabel 5. Hasil uji Chi Kuadrat perbedaan persentase persalinan preterm kadar HSP70 tidak normal dan kadar HSP70 normal

\begin{tabular}{lrrrrr}
\hline $\begin{array}{c}\text { Kadar } \\
\text { HSP70 }\end{array}$ & $\begin{array}{c}\text { Persalinan } \\
\text { preterm } \\
\text { N (\%) }\end{array}$ & $\begin{array}{c}\text { Kehamilan } \\
\text { Normal } \\
\mathbf{N ~ ( \% )}\end{array}$ & $\begin{array}{c}\text { Total } \\
\text { (\%) }\end{array}$ & PR & P \\
\hline$>12,5$ & 2 & 0 & 2 & 5,26 & 0,122 \\
& $(6,67)$ & $(0)$ & $(3,33)$ & & \\
$0-12,5$ & 28 & 30 & 58 & & \\
$\mathrm{ng} / \mathrm{ml}$ & $(93,33)$ & $(100)$ & $(96,67)$ & & \\
Total & $30(100)$ & $30(100)$ & $60(100)$ & & \\
\hline
\end{tabular}

\section{DISKUSI}

Hasil penelitian menunjukkan bahwa variabel umur, IMT, kadar hemoglobin, angka leukosit, kadar gula darah sewaktu, SGOT, SGPT, kadar ureum, kadar kreatinin, kadar total protein, serta tekanan darah sistolik dan diastolik antara dua kelompok penelitian tidak ada perbedaaan bermakna/homogen $(p>0,05)$. Hal ini menunjukkan variabel-variabel tersebut di atas tidak berpengaruh terhadap hasil penelitian.

Penelitian ini menunjukkan ada perbedaan bermakna pendidikan dan LILA antara persalinan pre term dan aterm. Hasil penelitian menunjukkan ibu hamil berpendidikan SD mempunyai risiko terjadi persalinan preterm sebanyak 6,6 kali lebih besar dibandingkan yang berpendidikan SMA. Berbeda dengan ibu berpendidikan SMP memiliki risiko untuk mengalami persalinan preterm sebanyak 3,2 kali lebih besar dibandingkan ibu berpendidikan SMA. Perbedaan ini berkaitan dengan kemampuan penerimaan dan pengelolaan stres psikososial, pemahaman ante natal care dan gizi ibu hamil serta gaya hidup (6).

Penilaian status gizi pada ibu hamil dapat dilakukan dengan cara pengukuran LILA, memantau pertambahan berat badan ibu selama hamil dan pemeriksaan spesimen berupa urine, tinja, darah, hati dan otot yang diuji secara laboratoris. Jika dibandingkan dengan indikator antropometri lainnya, maka LILA dinilai paling praktis penggunaannya di lapangan. Bahkan beberapa peneliti telah merekomendasikan LILA sebagai salah satu metode untuk dapat memprediksikan luaran kehamilan (12).

Penelitian ini menunjukkan bahwa ibu berstatus gizi kurang berhubungan dengan risiko terjadinya persalinan preterm. Ibu berstatus gizi kurang memiliki risiko untuk mengalami persalinan preterm sebanyak 5,5 kali lebih besar dibandingkan ibu berstatus gizi baik ( $P R=5,5$; $p=0,002$ ). Perbaikan status gizi pada ibu yang akan merencanakan kehamilan sangat penting untuk mencegah persalinan preterm. Penelitian Wadhwa et al juga mendukung bahwa kekurangan gizi selama masa prakonsepsi dan periode kehamilan dini akan menentukan luaran ibu dan janin yang jelek, termasuk persalinan preterm, yang ditandai meningkatnya efektor biologis stres, yaitu kortisol dan sitokin proinflamasi (13).

Variabel biologis HSP70 antara kedua kelompok penelitian terdapat perbedaan tetapi tidak bermakna $p=0,122$ $(p>0,05)$. Pada penelitian ini, hanya sedikit ibu yang mengalami persalinan preterm (2 kasus) dengan kadar HSP70 serum di atas normal, sedangkan pada kontrol tidak ada yang kadar HSP70 tinggi. Hal ini berarti bahwa HSP70 yang tinggi mempunyai risiko terjadi persalinan preterm sebanyak 5,2 kali lebih besar $(P R=5,27)$. Hasil itu kemungkinan karena HSP70 serum yang terukur merupakan HSP70 ekstraseluler sehingga tidak mewakili keberadaan HSP70 intraseluler. Perlu juga dikaji lebih mendalam kadar HSP70 pada persalinan preterm dengan cara membandingkan kadar HSP70 baik di dalam serum, plasenta dan amnion serta dengan jumlah sampel yang lebih banyak.

Terdapat beberapa pendapat tentang kadar HSP70 serum di dalam kehamilan normal pada penelitian-penelitian sebelumnya. Molvarec menyatakan bahwa kadar HSP70 meningkat secara bermakna seiring dengan bertambahnya umur kehamilan, namun pada penelitian Fukushima tidak didapatkan perubahan yang bermakna kadar HSP70 selama kehamilan (5).

Keterbatasan penelitian ini adalah desain penelitian potong lintang. Untuk melihat perubahan dan peranan kadar HSP70 pada inisiasi persalinan preterm perlu dilakukan penelitian lebih lanjut dengan desain penelitian kohort agar dapat dipelajari lebih mendalam pada individu yang sama. Desain penelitian potong lintang tidak bisa memberikan informasi perubahan kadar HSP70 yang berperan pada proses persalinan preterm, tetapi hanya memberikan informasi prevalensi persalinan preterm.

Kesimpulan pada penelitian ini adalah, ada perbedaan kadar Heat Shock Protein 70 pada ibu yang mengalami persalinan preterm dibandingkan kehamilan normal namun tidak bermakna. Kadar HSP70 yang tinggi mempunyai risiko 5,2 kali untuk terjadi persalinan preterm dibandingkan kadar HSP70 yang normal. Pada penelitan ini, variabel pendidikan dan lingkar lengan atas kiri (LILA) berpengaruh pada kejadian persalinan preterm. Pendidikan rendah (SD) berisiko untuk mengalami persalinan preterm sebanyak 6,6 kali lebih besar dibandingkan pendidikan lebih tinggi (SMA). Ukuran LILA kiri yang kurang berisiko untuk mengalami persalinan preterm sebanyak 5,5 kali lebih besar dibandingkan LILA kirinormal. 
Berdasarkan hasil penelitian, pengendalikan stresor psikososial sebelum dan awal kehamilan berperanan penting agar tidak terjadi peningkatan kadar HSP70 sehingga tidak terjadi persalinan preterm. Perlu penelitian

\section{DAFTAR PUSTAKA}

1. Krisnadi SR, Pramatirta AY, Siddiq A, dan Sitanggang E. Panduan Pengelolaan Persalinan Preterm Nasional. Bandung: Himpunan Kedokteran Fetomaternal; 2011.

2. George K, Prasad J, Singh D, et al. Perinatal Outcomes in a South Asian Setting with High Rates of Low Birth Weight. BioMed Central Pregnancy and Childbirth. 2009; 9(5): 1471-2393.

3. Latendresse G. The Interaction between Chronic Stress and Pregnancy: Preterm Birth from a Biobehavioral Perspective. Journal of Midwifery \& Womens Health. 2009; 54(1): 8-17.

4. Mendelson CR. Minireview: Fetal-Maternal Hormonal Signaling in Pregnancy and Labor. Molecular Endocrinology. 2009; 23(7): 947-954.

5. Molvarec A, Tamasi L, Losonczy G, Madach K, Prohaszka Z, and Rigo J Jr. Circulating Heat Shock Protein 70 (HSPA1A) In Normal And Pathological Pregnancies. Cell Stress and Chaperones. 2010;15:237-247

6. Kramer MS, Goulet L, Lydon J, et al. Sosio-Economic Disparities in Preterm Birth: Causal Pathways and Mechanisms. Paediatrics and Perinatology Epidemiology. 2001; 15(2): 104-123

7. Soetrisno. Ekspresi Heat Shock Protein 60, 70, 90 dan Kortisol pada Persalinan Ibu Primigravida yang Mendapat Psikokuratif. [Disertasi]. Universitas Airlangga, Surabaya. 2009. lebih lanjut untuk menilai peran HSP70 pada persalinan preterm dengan desain penelitian kohort dan dilakukan analisis multivariat untuk mengontrol faktor perancu (counfounding factor), yaitu LILA kiri dan pendidikan.

8. Gravett MG, Rubens CE, Nunes TM, and the GAPPS Review Group. Global Report on Preterm Birth and Stillbirth (2 of 7): Discovery Science. BioMed Central Pregnancy and Childbirth. 2010; 10(1): S2.

9. Koga K and Mor G. Toll-Like Receptors at the MaternalFetal Interface in Normal Pregnancy and Pregnancy Disorders. American Journal of Reproductive Immunology. 2010; 63(6): 587-600.

10. Noguchi T, Sado T, Naruse K, et al. Evidence For Activation of Toll-Like Receptor And Receptor For Advanced Glycation End Products In Preterm Birth. Mediators of Inflammation. 2010; 2010: 1-10

11. Murti B. Desain dan Ukuran Sampel untuk Penelitian Kuantitatif dan Kualitatif di Bidang Kesehatan. Yogyakarta: Gadjah Mada University Press; 2010: hal. 108-109.

12. Silitonga HN. Hubungan Antara Lingkar Lengan Atas Ibu Hamil dengan Berat Badan Bayi Lahir di Medan. [Tesis]. Universitas Sumatera Utara, Medan. 2011.

13. Wadhwa PD, Entringer S, Buss $\mathrm{C}$, and Lu MC. The Contribution of Maternal Stress to Preterm Birth: Issues and Considerations. Clinics in Perinatology. 2011;38(3):351-384.

14. Chaiworapongsa T, Erez O, Kusanovic JP, et al. Amniotic Fluid Heat Shock Protein 70 Concentration in Histologic Chorioamnionitis, Term and Preterm Parturition. Journal Maternal Fetal Neonatal Medicine. 2008; 21(7): 449-461. 